\title{
Association between TNF- $\alpha$ promoter G-308A and G-238A polymorphisms and obesity
}

\author{
M. Hedayati · K. Sharifi • F. Rostami • \\ M. S. Daneshpour · M. Zarif Yeganeh • \\ F. Azizi
}

Received: 14 August 2010/Accepted: 29 April 2011/Published online: 11 May 2011

(C) The Author(s) 2011. This article is published with open access at Springerlink.com

\begin{abstract}
Tumor necrosis factor- $\alpha$ (TNF- $\alpha)$, an adipokine, is produced in adipocytes, and the elevation of its levels has been linked to obesity and insulin resistance in some population. In this study the relationship between TNF- $\alpha$ promoter gene polymorphism and obesity in an Iranian population has been studied. Subjects were randomly selected from Tehran Cohort Lipid and Glucose Study. Adult participants placed in three groups according to their body mass index (BMI): $\mathrm{BMI}<25,25 \leq \mathrm{BMI}<30$, $\mathrm{BMI} \geq 30$ and under-18 subjects placed in two groups, under 85th percentile BMI and above 85th percentile. Finally, 244 persons were selected for G-308A and G-238A polymorphisms analysis. The FBS, high-density lipoprotein cholesterol (HDL-C), low-density lipoprotein cholesterol (LDL-C), triglyceride, cholesterol levels and blood pressure and HOMA of all subjects were measured. The polymorphism -308 and -238 were revealed by restriction fragment length polymorphism (RFLP; NCOI and MSPI) after the promoter site was amplified by PCR. The allele frequency of TNF- $\alpha$ polymorphism was in the Hardy-Weinberg equilibrium. There was no relation between $\mathrm{BMI}$ and the frequency of this allele. The fact that there is no association between G-308A and G-238A TNF$\alpha$ promoter polymorphisms and obesity probably shows
\end{abstract}

M. Hedayati $(\bowtie) \cdot$ K. Sharifi · F. Rostami ·

M. S. Daneshpour · M. Zarif Yeganeh

Obesity Research Center, Research Institute for Endocrine

Sciences, Shahid Beheshti University of Medical Sciences, 19395-4763, Tehran, Iran

e-mail: Hedayati@endocrine.ac.ir

F. Azizi

Endocrine Research Center, Research Institute for Endocrine Sciences, Shahid Beheshti University of Medical Sciences,

Tehran, Iran that it is not an important risk factor for obesity and consequently for cardiovascular disease.

Keywords Obesity $\cdot$ TNF- $\alpha \cdot$ BMI $\cdot$ Polymorphism

\section{Introduction}

There has been an increase of prevalence of obesity which is associated with several adverse health problems, including type 2 diabetes, hyperlipidemia and hypertension. The role obesity plays in the development of obesity-related disorders is complex and probably due to an interaction of genetic, nutritional and metabolic factors [1,2]. A number of candidate genes have been implicated in the pathogenesis of obesity in humans. Tumor necrosis factor- $\alpha$ (TNF- $\alpha$ ) is primarily secreted in adipocytes, and elevated levels of this cytokine have been linked to obesity and insulin resistance. TNF- $\alpha$ messenger RNA levels in skeletal muscle and adipose tissue of humans are positively correlated with body mass index (BMI), fat mass, and insulinemia and inversely correlated with lipoprotein lipase activity [3-5]. The gene which is coded human TNF- $\alpha$ is located on the short arm of chromosome 6 [6]. Recently, attention has been focused on two nucleotide polymorphisms identified in the promoter region of the TNF- $\alpha$ gene: $\mathrm{G} \rightarrow$ A substitutions at -308 and -238 respectively. In vitro experiments have demonstrated that the polymorphism -308 which is identified by $N c o$ I restriction fragment length polymorphism (RFLP), increases transcriptional activation of the TNF- $\alpha$ gene [7]. The potential functional impact of the polymorphism at position -238 of the TNF- $\alpha$ gene has not yet been investigated in in vitro expression studies. However, the variant is located within a putative $\mathrm{Y}$ box, which is a regulatory motif typical of the promoter region of major histocompatibility complex class II 
genes [8]. The purpose of the present study is to determine whether the two mentioned TNF- $\alpha$ promoter polymorphisms are associated with obesity in Iranian population.

\section{Materials and methods}

Subjects were randomly selected from Cohort Tehran Lipid and Glucose Study and adults were classified in three groups according to their BMI: BMI $<25$, $25 \leq$ BMI $<30$, BMI $\geq 30$. As for -308 polymorphism, 202 adults ( 81 men, 121 women) and 42 under-18 subjects ( 21 boys, 21 girls) were placed in two groups according to their BMI: under and above 85th percentile as far as age and sex are concerned. And as for -238 polymorphism, 239 (78 men, 120 women) and 41 under-18 subjects (17 boys, 24 girls) were classified in two groups according to their BMI: under and above 85th percentile as far as age and sex are concerned. BMI, waist to hip ratio, fat mass, and plasma concentration of glucose, serum levels of triglyceride, total cholesterol, and high-density lipoprotein (HDL) cholesterol were analyzed.

In order to genotype the subjects, the standard saltingout Proteinase $\mathrm{K}$ method was used to extract the germinal DNA. Both TNF- $\alpha$ promoter polymorphisms were detected using the RFLP method after amplification of the sequences by Polymerase Chain Reaction (PCR).

A 107-bp fragment encompassing the -308 variant site was amplified from genomic DNA by PCR using standard reagents, technique, and primers (5-AGG CAATAG GTTTTGAGGGGCCAT-3) and (5-TCCTCCCTGCTCCG ATTCCG-3) for the -308 variant and (5-ATCTGGA GGAAGCGGTAGTG-3) and (5-AGAAGACCCCCCTCG GAACC-3) for the -238 variant allele. To detect -308 variant alleles the PCR product was digested with $\mathrm{NcoI}$ at $37^{\circ} \mathrm{C}$ overnight, leaving a $107 \mathrm{bp}$ fragment when the variant was present and products of 87 and $20 \mathrm{bp}$ fragments for the normal allele visualized on 3\% agarose gel. To detect the -238 variant alleles, the PCR product was digested with $\mathrm{MspI}$ at $37^{\circ} \mathrm{C}$ for an hour, leaving a $152 \mathrm{bp}$ fragment when the variant was present and products of 133 and $19 \mathrm{bp}$ fragments for the normal allele visualized on $3 \%$ agarose gel.

\section{Statistical analysis}

Normality distribution of the data checked by the KS test. The mean levels of all normally-distributed variants were tested by ANOVA and the mean levels of all abnormallydistributed variants were tested by nonparametric KruskalWallis $\mathrm{H}$ test and the data were presented as means $\pm \mathrm{SD}$ of the differences. All analyses were conducted using the SPSS 16 software.

\section{Results}

Genotype frequencies in all groups were in accordance with the Hardy-Weinberg equilibrium. The distribution of TNF- $\alpha$ genotype for -308 site in under-18 subjects was as follows: GG (81\%), GA (16.6\%), and AA (2.4\%). In adults the following results were produced: GG $(86.6 \%)$, GA $(12.4 \%)$, and AA $(1 \%)$. As for the -238 site in under-18 subjects the results were: GG $(80.5 \%)$, GA $(19.5 \%)$, and AA $(0 \%)$, and in adults the following results were recorded: GG (79.3\%), GA (19.2\%), and AA (1.5\%). Clinical and biochemical data of participants, when classified in accordance to G/A polymorphisms at positions -308 and -238 of the TNF- $\alpha$ gene promoter, are presented in Table $1(-308)$ and Table $2(-238)$. To examine whether the variant alleles were more common in patients with obesity, adults were classified in three groups according to their $\mathrm{BMI}: \mathrm{BMI}<25,25 \leq \mathrm{BMI}<30$, $\mathrm{BMI} \geq 30$ and under-18 subjects were classified in two groups according to their BMI: under 85 th percentile BMI and above 85 th percentile as far as age and sex are concerned-Table 3 $(-308)$ and Table $4(-238)$.

\section{Discussion}

The purpose of the present study is to determine whether the $\mathrm{G} \rightarrow$ A polymorphisms of the TNF- $\alpha$ gene promoter are associated with obesity and anthropometric parameters in Cohort Tehran Lipid and Glucose study. There are no associations between G-308A and G-238A TNF- $\alpha$ promoter polymorphisms and increases in BMI. TNF- $\alpha$ is one of the cytokines secreted from adipose tissue in obesity; it can be a candidate gene to inspect obesity and related diseases. Obesity is a complex metabolic disorder with a strong genetic component and there are many candidate genes for obesity and its related phenotypes. Most of these genes are candidate because their mutations cause rare genetic syndromes affecting adipocytes differentiation [9]. Recent interest has focused on the role of the TNF- $\alpha$ gene in insulin resistance and obesity. We therefore examined the association between the polymorphism of TNF- $\alpha$ and obesity without metabolic disease. It came as another study reported an association between this genetic marker and excessive fat accumulation in women [10].

Moreover, a potential role for the TNF- $\alpha$ locus in obesity is also supported by a linkage study, which reported a relationship between the TNF- $\alpha$ locus and various global measures of adiposity in Pima Indians and European Caucasians $[11,12]$. The functional role of the TNF- $\alpha$ G-308A polymorphism is currently unclear. However, it is located within a consensus sequence for the transcription factor AP-2 in the promoter region of the gene [13]. 
Table 1 Clinical and biochemical data of subjects when classified in accordance to the genotype of the G/A polymorphisms at positions -308 of the TNF- $\alpha$ gene promoter

\begin{tabular}{|c|c|c|c|c|c|c|c|c|}
\hline \multicolumn{5}{|l|}{ Under 18} & \multicolumn{4}{|l|}{ Above 18} \\
\hline Trait & GG (34) & GA (7) & AA (1) & $P$ & GG (175) & GA (25) & AA (2) & $P$ \\
\hline Age (years) & $12.51 \pm 2.8$ & $14.21 \pm 2.25$ & 10.5 & 0.240 & $43.34 \pm 15.62$ & $40.96 \pm 16.04$ & $51.25 \pm 1.76$ & 0.591 \\
\hline $\operatorname{Sex}(M / F)$ & $17 / 17$ & $3 / 4$ & $1 / 0$ & 0.572 & $70 / 105$ & $10 / 15$ & $1 / 1$ & 0.960 \\
\hline BMI $\left(\mathrm{kg} / \mathrm{m}^{2}\right)$ & $19.73 \pm 3.84$ & $19.91 \pm 2.07$ & 26.71 & 0.179 & $26.65 \pm 4.55$ & $27.33 \pm 4.82$ & $32.18 \pm 2.7$ & 0.196 \\
\hline FBS (mg/dl) & $86.45 \pm 5.62$ & $87.35 \pm 6.51$ & 73.5 & 0.088 & $89.00 \pm 22.18$ & $90.50 \pm 8.66$ & $87.5 \pm 7.07$ & 0.865 \\
\hline HOMA & $10.1 \pm 5.80$ & $9.45 \pm 2.87$ & 12.15 & 0.889 & $12.13 \pm 281.39$ & $12.36 \pm 8.83$ & $10.15 \pm 0.02$ & 0.683 \\
\hline $\mathrm{CHO}(\mathrm{mg} / \mathrm{dl})$ & $158.57 \pm 2.44$ & $169.79 \pm 22.38$ & 178.00 & 0.421 & $196.57 \pm 42.73$ & $197.00 \pm 47.91$ & $208.75 \pm 44.90$ & 0.925 \\
\hline HDL-C (mg/dl) & $44.30 \pm 8.60$ & $43 \pm 7.34$ & 29 & 0.208 & $42.26 \pm 9.63$ & $42.76 \pm 9.20$ & $31.75 \pm 13.78$ & 0.295 \\
\hline LDL-C (mg/dl) & $95.96 \pm 20.75$ & $109.69 \pm 22.87$ & 113.40 & 0.241 & $124.53 \pm 3.46$ & $118.52 \pm 43.83$ & $128.75 \pm 40.09$ & 0.723 \\
\hline TG (mg/dl) & $94.44 \pm 39.00$ & $85.85 \pm 21.80$ & 178.50 & 0.074 & $128.50 \pm 81.07$ & $142.50 \pm 154.54$ & $241.25 \pm 44.19$ & 0.053 \\
\hline WHR & $0.83 \pm 0.05$ & $0.82 \pm 0.07$ & 0.98 & 0.053 & $0.87 \pm 0.08$ & $0.86 \pm 0.09$ & $0.95 \pm 0.06$ & 0.344 \\
\hline $\mathrm{SBP}(\mathrm{mmHg})$ & $101.31 \pm 8.46$ & $104.21 \pm 5.12$ & 97 & 0.579 & $114.50 \pm 17.26$ & $116.50 \pm 11.02$ & $131.25 \pm 22.27$ & 0.426 \\
\hline DBP (mmHg) & $67.22 \pm 5.85$ & $71.21 \pm 4.87$ & 57.5 & 0.059 & $74.36 \pm 8.09$ & $75.34 \pm 8.98$ & $83 \pm 16.26$ & 0.303 \\
\hline
\end{tabular}

Table 2 Clinical and biochemical data subjects when classified in accordance to the genotype of the G/A polymorphisms at positions -238 of the TNF- $\alpha$ gene promoter

\begin{tabular}{|c|c|c|c|c|c|c|c|c|}
\hline \multicolumn{5}{|l|}{ Under 18} & \multicolumn{4}{|l|}{ Above 18} \\
\hline Trait & GG (33) & GA (8) & $\mathrm{AA}(0)$ & $P$ & GG (175) & GA (38) & AA (3) & $P$ \\
\hline Age (years) & $13.24 \pm 2.96$ & $12.62 \pm 2.21$ & - & 0.585 & $42.18 \pm 15.01$ & $39.93 \pm 16.50$ & $42.50 \pm 21.07$ & 0.585 \\
\hline $\operatorname{Sex}(M / F)$ & $13 / 20$ & $4 / 4$ & - & 0.589 & $97 / 60$ & $17 / 21$ & $1 / 2$ & 0.745 \\
\hline BMI $\left(\mathrm{kg} / \mathrm{m}^{2}\right)$ & $20.12 \pm 3.58$ & $19.08 \pm 2.88$ & - & 0.454 & $26.40 \pm 4.37$ & $26.84 \pm 4.71$ & $23.37 \pm 3.12$ & 0.415 \\
\hline FBS (mg/dl) & $87.63 \pm 6.24$ & $84.50 \pm 6.83$ & - & 0.218 & $89 \pm 41.62$ & $87.25 \pm 23.13$ & $89 \pm 13.47$ & 0.766 \\
\hline HOMA & $10.79 \pm 6.42$ & $10.28 \pm 3.03$ & - & 0.828 & $12.13 \pm 8.85$ & $10.15 \pm 9.18$ & $10.19 \pm 1.04$ & 0.158 \\
\hline $\mathrm{CHO}(\mathrm{mg} / \mathrm{dl})$ & $162.18 \pm 23.99$ & $146.38 \pm 26.83$ & - & 0.110 & $199.08 \pm 40.46$ & $183.78 \pm 37.69$ & $214.17 \pm 92.59$ & 0.090 \\
\hline HDL-C (mg/dl) & $43.83 \pm 7.62$ & $43.12 \pm 7.80$ & - & 0.816 & $42.85 \pm 9.03$ & $42.18 \pm 10.25$ & $41.66 \pm 4.19$ & 0.904 \\
\hline LDL-C (mg/dl) & $100.08 \pm 19.52$ & $87.30 \pm 27.62$ & - & 0.134 & $125.92 \pm 34.11$ & $112.62 \pm 32.22$ & $148.07 \pm 83.89$ & 0.052 \\
\hline TG (mg/dl) & $94.30 \pm 37.85$ & $80 \pm 30.23$ & - & 0.328 & $123.00 \pm 97.55$ & $145.25 \pm 57.70$ & $103.50 \pm 56.73$ & 0.519 \\
\hline WHR & $0.82 \pm 0.04$ & $0.8 \pm 0.11$ & - & 0.451 & $0.87 \pm 0.08$ & $0.87 \pm 0.1$ & $0.83 \pm 0.11$ & 0.780 \\
\hline $\mathrm{SBP}(\mathrm{mmHg})$ & $100.42 \pm 8.51$ & $104.56 \pm 7.72$ & - & 0.217 & $115.14 \pm 15.20$ & $115.86 \pm 15.04$ & $103 \pm 21.65$ & 0.757 \\
\hline $\mathrm{DBP}(\mathrm{mmHg})$ & $66.33 \pm 5.17$ & $70.12 \pm 6.28$ & - & 0.082 & $73.88 \pm 7.80$ & $75.46 \pm 7.71$ & $70.83 \pm 6.65$ & 0.407 \\
\hline
\end{tabular}

The G-308A mutation in the promoter region of TNF- $\alpha$ acts in vitro as a much stronger transcriptional activator than the wild-type TNF- $\alpha$ and it is suggested that a higher transcriptional activity would result in higher TNF- $\alpha$ concentrations followed by decreased insulin sensitivity [7]. So this variant could play a role in the development of obesity and related phenotypes [14]. Interestingly, obesity is known to be associated with increased levels of TNF- $\alpha$ mRNA and protein in fat tissue both in humans and in genetically obese or diabetic rodents [15]. Moreover, a study has shown that the TNF- $\alpha$ mRNA level in adipose tissue are significantly correlated with the percentage of body fat in human obese subjects [5]. A recent study, while confirming linkage between the TNF- $\alpha$ locus and obesity in families of French-Canadian origin, has also found a significant association between this locus and high blood pressure [16]. A significant positive correlation between serum TNF- $\alpha$ concentration and systolic blood pressure has also been reported among individuals of an isolated native Canadian population over a wide range of adiposity [17]. An Italian population study suggests that the G-308A mutation of the TNF- $\alpha$ gene is unlikely to play an important role in the development of obesity and its related metabolic abnormalities such as insulin resistance and dyslipidemia [18]. As for the G-238A variant, previous results are also inconsistent. A study of non-diabetic 
Table 3 Clinical and biochemical data of subjects when classified in accordance to BMI for polymorphisms at positions -308 of the TNF- $\alpha$ gene promoter

\begin{tabular}{|c|c|c|c|c|c|c|c|}
\hline \multicolumn{4}{|l|}{ Under 18} & \multicolumn{4}{|l|}{ Above 18} \\
\hline Trait & $\begin{array}{l}\text { Grade } 1 \\
\text { BMI }<85 \% \\
(n=26)\end{array}$ & $\begin{array}{l}\text { Grade } 2 \\
\mathrm{BMI}>85 \% \\
(n=16)\end{array}$ & $P$ & $\begin{array}{l}\text { Grade } 1 \\
\text { BMI }<25 \\
(n=75)\end{array}$ & $\begin{array}{l}\text { Grade } 2 \\
25 \leq \mathrm{BMI}<30 \\
(n=81)\end{array}$ & $\begin{array}{l}\text { Grade } 3 \\
\mathrm{BMI} \geq 30 \\
(n=46)\end{array}$ & $P$ \\
\hline GG & $21(80.8 \%)$ & $13(81.2 \%)$ & - & $67(89.3 \%)$ & $71(87.7 \%)$ & $37(80.4 \%)$ & - \\
\hline GA & $5(19.2 \%)$ & $2(12.51 \%)$ & - & $8(10.7 \%)$ & $10(12.3 \%)$ & $7(15.2 \%)$ & - \\
\hline AA & - & $1(6.2 \%)$ & - & - & - & $2(4.3 \%)$ & - \\
\hline Age (years) & $12.88 \pm 2.76$ & $12.53 \pm 2.81$ & 0.692 & $36.37 \pm 16.65$ & $45.56 \pm 14.36$ & $49.85 \pm 11.46$ & 0.000 \\
\hline BMI $\left(\mathrm{kg} / \mathrm{m}^{2}\right)$ & $17.64 \pm 2.03$ & $2.60 \pm 23.63$ & 0.000 & $22.27 \pm 1.93$ & $27.49 \pm 1.42$ & $32.90 \pm 3.37$ & 0.000 \\
\hline FBS (mg/dl) & $86.34 \pm 6.21$ & $86.34 \pm 6.21$ & 0.948 & $87 \pm 21.07$ & $91 \pm 16.66$ & $91.50 \pm 26.02$ & 0.001 \\
\hline HOMA & $9.94 \pm 4.80$ & $10.22 \pm 6.27$ & 0.870 & $12.34 \pm 10.18$ & $12.47 \pm 413.40$ & $10.31 \pm 5.78$ & 0.071 \\
\hline $\mathrm{CHO}(\mathrm{mg} / \mathrm{dl})$ & $155.9 \pm 22.13$ & $169.03 \pm 25.49$ & 0.086 & $181.50 \pm 42.11$ & $201.32 \pm 43.50$ & $213.51 \pm 36.66$ & 0.000 \\
\hline HDL-C (mg/dl) & $43.19 \pm 7.74$ & $44.59 \pm 9.93$ & 0.612 & $42.53 \pm 9.18$ & $36.98 \pm 8.37$ & $45.62 \pm 11.34$ & 0.005 \\
\hline LDL-C (mg/dl) & $96.12 \pm 19.71$ & $102.79 \pm 23.82$ & 0.332 & $113.77 \pm 36.47$ & $125.82 \pm 34.53$ & $136.71 \pm 32.79$ & 0.002 \\
\hline $\mathrm{TG}(\mathrm{mg} / \mathrm{dl})$ & $86.78 \pm 27.92$ & $108.37 \pm 49.33$ & 0.077 & $108 \pm 67.10$ & $154.50 \pm 117.21$ & $135.25 \pm 70.22$ & 0.000 \\
\hline WHR & $0.81 \pm 0.05$ & $0.86 \pm 0.06$ & 0.008 & $0.83 \pm 0.07$ & $0.89 \pm 0.08$ & $0.9 \pm 0.07$ & 0.000 \\
\hline $\mathrm{SBP}(\mathrm{mmHg})$ & $100.78 \pm 8.14$ & $103.15 \pm 7.65$ & 0.355 & $111.50 \pm 11.78$ & $116 \pm 18$ & $119 \pm 17.75$ & 0.000 \\
\hline DBP $(\mathrm{mmHg})$ & $67.51 \pm 6.36$ & $67.87 \pm 5.52$ & 0.854 & $71.57 \pm 7.23$ & $75.51 \pm 8.11$ & $77.79 \pm 8.69$ & 0.000 \\
\hline
\end{tabular}

Table 4 Clinical and biochemical data of subjects when classified in accordance to BMI for polymorphisms at positions -238 of the TNF- $\alpha$ gene promoter

\begin{tabular}{|c|c|c|c|c|c|c|c|}
\hline \multicolumn{4}{|l|}{ Under 18} & \multicolumn{4}{|l|}{ Above 18} \\
\hline Trait & $\begin{array}{l}\text { Grade } 1 \\
\mathrm{BMI}<85 \% \\
(n=26)\end{array}$ & $\begin{array}{l}\text { Grade } 2 \\
\mathrm{BMI}>85 \% \\
(n=16)\end{array}$ & $P$ & $\begin{array}{l}\text { Grade } 1 \\
\text { BMI }<25 \\
(n=75(\end{array}$ & $\begin{array}{l}\text { Grade } 2 \\
25 \leq \mathrm{BMI}<30 \\
(n=81)\end{array}$ & $\begin{array}{l}\text { Grade } 3 \\
\mathrm{BMI} \geq 30 \\
(n=46)\end{array}$ & $P$ \\
\hline GG & $21(80.8 \%)$ & $13(80 \%)$ & - & $65(81.2 \%)$ & $60(77.9 \%)$ & $32(78 \%)$ & - \\
\hline GA & $5(19.2 \%)$ & $2(20 \%)$ & - & $13(16.2 \%)$ & $16(20.8 \%)$ & $9(22 \%)$ & - \\
\hline $\mathrm{AA}$ & - & - & - & $2(2.5 \%)$ & $1(1.3 \%)$ & - & - \\
\hline Age (years) & $13.50 \pm 2.75$ & $12.46 \pm 2.90$ & 0.264 & $38 \pm 16.61$ & $42.42 \pm 13.85$ & $50.24 \pm 12.16$ & 0.000 \\
\hline $\mathrm{BMI}\left(\mathrm{kg} / \mathrm{m}^{2}\right)$ & $18.05 \pm 2.28$ & $23.15 \pm 2.63$ & 0.000 & $22.27 \pm 1.89$ & $27.50 \pm 1.43$ & $32.57 \pm 3.18$ & 0.000 \\
\hline FBS (mg/dl) & $86.86 \pm 7.21$ & $87.30 \pm 4.88$ & 0.837 & $87 \pm 54$ & $89 \pm 26.03$ & $92 \pm 15.04$ & 0.011 \\
\hline HOMA & $10.97 \pm 5.69$ & $10.21 \pm 6.39$ & 0.696 & $11.32 \pm 8.92$ & $12.14 \pm 9.73$ & $10.44 \pm 6.73$ & 0.385 \\
\hline $\mathrm{CHO}(\mathrm{mg} / \mathrm{dl})$ & $154.36 \pm 22.76$ & $167.30 \pm 27.41$ & 0.112 & $186.30 \pm 41.59$ & $200.50 \pm 42.15$ & $208.26 \pm 34.04$ & 0.011 \\
\hline HDL-C (mg/dl) & $42.19 \pm 6.31$ & $46.30 \pm 8.99$ & 0.094 & $43.35 \pm 8.64$ & $40.66 \pm 8.26$ & $45.30 \pm 11.39$ & 0.023 \\
\hline LDL-C (mg/dl) & $95.35 \pm 19.41$ & $101.44 \pm 25.09$ & 0.391 & $117.18 \pm 36.66$ & $126.27 \pm 34.73$ & $131.60 \pm 30.38$ & 0.071 \\
\hline $\mathrm{TG}(\mathrm{mg} / \mathrm{dl})$ & $87.8 \pm 29.78$ & $97.93 \pm 46.60$ & 0.4 & $110.50 \pm 69.11$ & $144.50 \pm 111.46$ & $135 \pm 69.81$ & 0.000 \\
\hline WHR & $0.80 \pm 0.06$ & $0.85 \pm 0.05$ & 0.012 & $0.83 \pm 0.08$ & $0.89 \pm 0.08$ & $0.89 \pm 0.08$ & 0.000 \\
\hline $\mathrm{SBP}(\mathrm{mmHg})$ & $99.4 \pm 8.42$ & $104.4 \pm 7.71$ & 0.067 & $111.75 \pm 12.67$ & $115 \pm 14.84$ & $118.5 \pm 17.34$ & 0.001 \\
\hline DBP (mmHg) & $66.94 \pm 5.68$ & $67.30 \pm 5.45$ & 0.845 & $72.11 \pm 7.22$ & $74.13 \pm 7.54$ & $78.09 \pm 7.87$ & 0.000 \\
\hline
\end{tabular}

relatives and control subjects in Britain showed that the -238 variant was associated with increased insulin sensitivity as estimated by two independent methods [19]. A recent meta-analysis (2,106 cases and 2,920 controls) of the rs361525 (G-238A) variant has not detected a significant association with type 2 diabetes [20], nor has the study of Caucasian and African American subjects [21]. $\mathrm{Be}^{\prime} \mathrm{ne}^{\prime}$ dicte Fontaine-Bisson and co-workers suggest that the $-238 \mathrm{G} \rightarrow \mathrm{A}$ and $-308 \mathrm{G} \rightarrow \mathrm{A}$ polymorphisms of $\mathrm{TNF}-\alpha$ alter circulating free fatty acids and insulin resistance in obese subjects with type 2 diabetes mellitus [22]. 
Acknowledgment This study was supported by a research grant from Endocrine Research Center, Shahid Beheshti University of Medical Sciences. We are indebted to kind collaboration of several endocrinology specialists. We express our gratitude to the staff of Molecular Genetic Laboratory at Endocrine Research Center, for their skillful technical assistance.

Open Access This article is distributed under the terms of the Creative Commons Attribution Noncommercial License which permits any noncommercial use, distribution, and reproduction in any medium, provided the original author(s) and source are credited.

\section{References}

1. Hart CL, Hole DJ, Lawlor DA, Smith GD (2007) Obesity and use of acute hospital services in participants of the Renfrew/Paisley study. J Public Health (Oxf) 29:53-56

2. Shuldiner AR (2008) Obesity genes and gene-environmentbehavior interactions: recommendations for a way forward obesity (silver spring). Obesity 16:S79-S81. doi:10.1038/oby. 2008.523

3. Pomp D, Mohlke KL (2008) Obesity genes: so close and yet so far. Sci J Biol 7:36. doi:10.1186/jbiol93

4. Saghizadeh M, Ong JM, Garvey WT, Henry RR, Kern PA (1996) The expression of TNF a by human muscle. Relationship to insulin resistance. J Clin Investig 97:1111-1116

5. Kern PA, Saghizadeh M, Ong JM, Bosch RJ, Deem R, Simsolo RB (1995) The expression of tumor necrosis factor in human adipose tissue. Regulation by obesity, weight loss, and relationship to lipoprotein lipase. J Clin Investig 95:2111-2119

6. Nedwin GE, Naylor SL, Sakaguchi AY, Smith D, Jarrett-Nedwin J, Pennica D et al (1985) Human lymphotoxin and tumor necrosis factor genes: structure, homology and chromosomal localization. Nucleic Acids Res 13:6361-6373

7. Wilson AG, Symons JA, McDowell TL, McDevitt HO, Duff GW (1997) Effects of a polymorphism in the human tumor necrosis factor $\alpha$ promoter on transcriptional activation. Proc Natl Acad Sci USA 94:3195-3199

8. D'Alfonso S, Richiardi PM (1994) A polymorphic variation in a putative regulation box of the TNFA promoter region. Immunogenetics 39:150-154

9. Bouchard C, Perusse L, Leblac C, Tremblay A, Theriault G (1998) Inheritance of the amount and distribution of human body fat. Int J Obes 12:205-215

10. Hoffstedt J, Eriksson P, HellstroÈm L, RoÈssner S, RydeÂn M, Arner P (2000) Excessive fat accumulation is associated with the $\mathrm{TNFa}-308 \mathrm{G} \rightarrow$ A promoter polymorphism in women but in men. Diabetologia 43:117-120
11. FernaÂndez-Real JM, Gutierrez C, Ricart W, Casamitjana R, FernaÂndez-Castaner M, Vendrell J et al (1997) The TNF-alpha gene NcoI polymorphism influences the relationship among insulin resistance, percent body fat, and increased serum leptin levels. Diabetes 46:1468-1472

12. Norman RA, Bogardus C, Ravussin E (1995) Linkage between obesity and a marker near the tumor necrosis factor-alpha locus in Pima Indians. J Clin Investig 96:158-162

13. Wilson AG, Di Giovine FS, Blakemore AI, Duff GW (1992) Single base polymorphism in the human tumour necrosis factor alpha (TNF alpha) gene detectable by NcoI restriction of PCR product. Hum Mol Genet 1:353

14. Hotamisligil GS, Spiegelman BM (1994) Tumor necrosis factor alpha: a key component of the obesity-diabetes link. Diabetes 43:1271-1278

15. Hotamisligil GS, Shargill NS, Spiegelman BM (1993) Adipose expression of tumor necrosis factor-a: direct role in obesitylinked insulin resistance. Science 259:87-91

16. Pausova Z, Deslauriers B, Gaudet D, Tremblay J, Kotchen TA, Larochelle P et al (2000) Role of tumor necrosis factor alpha gene locus in obesity and obesity-associated hypertension in French Canadians. Hypertension 36:14-19

17. Zinman B, Hanley AJ, Harris SB, Kwan J, Fantus IG (1999) Circulating tumor necrosis factor-alpha concentrations in a native Canadian population with high rates of type 2 diabetes mellitus. J Clin Endocrinol Metab 84:272-278

18. Romeo S, Sentinelli F, Capici F, Arca M, Berni A, Vecci E, Di Mario U, Baroni MG (2001) The G-308A variant of the Tumor Necrosis Factor- $\alpha(\mathrm{TNF}-\alpha)$ gene is not associated with obesity, insulin resistance and body fat distribution. BMC Med Genet 2:10. doi:10.1186/1471-2350-2-10

19. Day CP, Grove J, Daly AK, Stewart MW, Avery PJ, Walker M (1998) Tumour necrosis factor-a gene promoter polymorphism and decreased insulin resistance. Diabetologia 41:430-434

20. Feng R, Li Y, Zhao D, Wang C, Niu Y, Sun C (2009) Lack of association between TNF $-238 \mathrm{G} / \mathrm{A}$ polymorphism and type 2 diabetes: a meta-analysis. Acta Diabetol 46(4):339-343. doi: 10.1007/s00592-009-0118-3

21. Walston J, Seibert M, Yen C, Cheskin LJ, Andersen RE (1999) Tumor necrosis factor-a-238 and -308 polymorphisms do not associate with traits related to obesity and insulin resistance. Diabetes 48:2096-2098

22. Fontaine-Bisson B, Wolever TM, Chiasson JL, Rabasa-Lhoret R, Maheux P, Josse RG, Leiter LA, Rodger NW, Ryan EA, ElSohemy A (2007) Tumor necrosis factor alpha -238G $>$ A genotype alters postprandial plasma levels of free fatty acids in obese individuals with type 2 diabetes mellitus. Metabolism 56(5):649-655 